Discussion Paper No. 05-61

Do University Based Regions Really Attract Outside Entrepreneurs The Case of the German Biotechnology Industry

Dirk Engel and Oliver Heneric

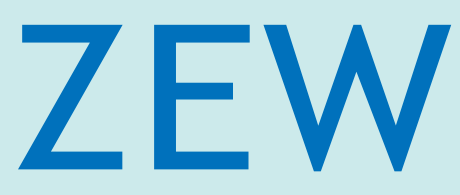

Zentrum für Europäische Wirtschaftsforschung $\mathrm{GmbH}$ Centre for European Economic Research 
Discussion Paper No. 05-61

\section{Do University Based Regions Really Attract Outside Entrepreneurs - The Case of the German Biotechnology Industry}

Dirk Engel and Oliver Heneric

Download this ZEW Discussion Paper from our ftp server:

ftp://ftp.zew.de/pub/zew-docs/dp/dp0561.pdf

Die Discussion Papers dienen einer möglichst schnellen Verbreitung von neueren Forschungsarbeiten des ZEW. Die Beiträge liegen in alleiniger Verantwortung der Autoren und stellen nicht notwendigerweise die Meinung des ZEW dar.

Discussion Papers are intended to make results of ZEW research promptly available to other economists in order to encourage discussion and suggestions for revisions. The authors are solely responsible for the contents which do not necessarily represent the opinion of the ZEW. 


\section{Non-technical Summary}

Economic research suggests that public research institutions and universities play an important role to push the formation of new technology based firms in university-based regions. Thus, we observe a significant higher number of new-technology based firms close to private and public research institutions. The positive relationship may result from the start-up decision of local scientists which are highly embedded in a region's research network. A second argument emphasizes the attractiveness of university-based regions for so called non-embedded entrepreneurs. These entrepreneurs have either weaker linkages to a region's research network or existing linkages imply higher transaction costs based on spatial distance. Non-embedded entrepreneurs can potentially be attracted by a region's knowledge base to establish a new firm in this region.

The study provides first empirical evidence of its kind to test whether university-based regions succeed in attracting non-embedded entrepreneurs. This question is particularly important with respect to the emergence of new industries. Public authorities have only a minor time slot to attract mobile founders. We test the attractiveness hypothesis for the modern German biotechnology industry. Biotechnology is an excellent example for a new knowledge based industry that is characterized by an extensive use of basic science knowledge.

The ZEW-Foundation Panel and a computer-assisted search for relevant strings are used to identify biotechnology firms to form the database for the study. We consider 1,886 entrepreneurs who are acting in 874 newly founded biotech-firms between 1995 and 2003. We apply a count data model to analyze the relationship between knowledge and the number of entrepreneurs of biotech start-up rates on the level of German counties. Our empirical analysis allows differences between several knowledge sources groups of entrepreneurs.

Results of our multivariate analysis indicate a high start-up activity in knowledge intensive regions. Group differentiation shows that knowledge stock variables matter only for academic founders inside as well as outside the region. In contrast, the start-up activity of non-academic founders coming from inside or outside the region cannot be explained with knowledge intensity of the region. Our empirical results suggest that knowledge spillovers really matter for outsiders, but these spillovers only attract founders with a high affinity to research. The message for regional policy is clear and evident: Efforts to improve regions' knowledge base and its signalizing really attract mobile founders from other regions. 


\title{
Do University Based Regions Really Attract Outside Entrepreneurs - The Case of the German Biotechnology Industry*
}

\author{
by \\ Dirk Engel $^{1}$ and Oliver Heneric ${ }^{2}$ \\ ${ }^{1}$ Rheinisch Westfälisches Institut für Wirtschaftsforschung (RWI Essen), \\ engel@rwi-essen.de \\ ${ }^{2}$ Centre for European Economic Research (ZEW), heneric@zew.de,
}

\begin{abstract}
The paper tests empirically the role of knowledge stocks to explain the regional distribution of Germany's biotechnology founders. We present an unique approach to highlight the role of knowledge spillovers as we differentiate according the local embeddedness and research affinity of founders. As expected, the results of our multivariate analysis indicate a high start-up activity in knowledge intensive regions. Group differentiation shows that knowledge stock variables matter only for academic founders inside as well as outside the region. In contrast, the start-up activity of non-academic founders coming from inside or outside the region cannot be explained with knowledge intensity of the region. Our empirical results suggest that knowledge spillovers matter, but these spillovers only attract founders with high affinity to research.
\end{abstract}

Keywords: Biotechnology, start-ups, economic geography, intellectual capital, count data model

JEL Classification: $\quad R 30, C 21, R 58, O 30$

* Thanks to Thomas K. Bauer, Georg Licht, Christian Rammer and participants of the meetings of "Gesellschaft für Regionalforschung" and "Regionalausschuss des Vereins für Socialpolitik" in year 2004 for valuable comments and discussion. All remaining errors and shortcomings are, of course, the responsibility of the authors alone. 


\section{Introduction}

Many empirical studies show that university-based regions realize higher formation rates of new technology-based firms (e.g. Bania et al. 1993, Storey and Tether 1996, Harhoff 1997, Nerlinger 1998). The positive relationship may result from the startup decision of local scientists, which are highly embedded in region's research network. A second argument emphasize the attractiveness of university-based regions for non-embedded entrepreneurs. These kind of entrepreneurs have weaker linkages to region's research network or existing linkages imply higher transaction costs based on spatial distance.

The study provides first empirical evidence of its kind to test the relevance of the second argument. The question about attracting non-embedded entrepreneurs, especially entrepreneurs outside the region, is particular important with respect to the emergence of new industries which is characterized by fast growing number of start-ups (see Klepper 1996) and regional clustering in first years. In the consequence, public authorities have only a minor time slot to attract mobile founders. We test the attractiveness hypothesis for the modern German biotechnology industry. Biotechnology is an excellent example for a new knowledge based industry that is characterized by an extensively use of basic science knowledge. This new knowledge tends to be produced in tacit form. Regions provided with high level of biotechnology relevant knowledge seem to have best chances to attract potential entrepreneurs to establish a biotech-firm in these particular regions. This assumption follows from both the tacit knowledge concept combined with localized spillover concept. Tacit knowledge is partially rivalrous and needs spatial proximity between knowledge creators and its users to commercialize new knowledge in new product or process applications. 
Zucker et al. (1998) developed a sophisticated approach by focusing on star scientists which report genetic-sequence discoveries in GenBank ${ }^{1}$ (1990) since April 1990. They observe a significant relationship between the number of star scientist at public research institutions and the number of start-ups in the same region. The key message is that spatial proximity matters. Their study does not answer, however, whether spatial proximity matters for both inside as well as outside entrepreneurs. Results of some papers emphasize the relevance of outside entrepreneurs. For example, Audretsch and Stephan (1996: 647) show that 42 per cent of universitybased founders moved out their region to be involved as shareholder in biotech firms outside their region. Egeln et al. (2004: 213) report that the distance between firm location and parent institution reaches 50 kilometres and more for one third of public research spin-offs. Probably, knowledge-spillover pulls outside entrepreneurs to move in the region.

We apply a count data model to analyze the relationship between knowledge and start-up rates on the level of German counties. Our empirical analysis allows to point out differences between several knowledge sources for different groups of entrepreneurs. Thus, we learn something more about the importance of different research institution and regional conditions to attract inside and outside entrepreneurs.

Our paper is organised as follows. In section two we give some background information regarding the determinants of start-up activities in the biotechnology industry. Database description and some descriptive results concerning regional differences in the start-up activity are followed in section three. Section four deals with the explanation of observed regional differences of start-up activities. We present the econometric approach briefly and emphasize the interpretation of the

1 GenBank is an annotated collection of all publicly available DNA sequences (http://www.psc.edu/general/software/packages/genbank/genbank.html [26.3.2004]). 
estimation results in this section. Main results are summarized and concluding remarks are given in section five.

\section{Conceptual Framework}

New biotech firms are predominantly, independent companies; that is, individuals typically have a stake in their foundation. Market entries by established firms are less common. These aspects are typical for new, technology-intensive industries' early-phase emergence (cp. Winter 1984, Agarwal and Audretsch 2001).

Every independent firm foundation in a region is the result of two entrepreneurial decisions: first the decision to take over entrepreneurial function (= foundation decision) and second the choice of location. Both can occur either simultaneously or successively. Further, the availability of suitable locations is presumed to influence the foundation decision. The foundation decision is a matter of economical, sociological and psychological revision (Pfeiffer 1994, Brüderl et al. 1996, Frick et al. 1998), while one can rely on location-related theories of micro- and macroeconomic units in explaining theoretical motivations behind the choice of location (Marshall 1890, Weber 1909, Böventer 1979, Gehrung 1996). In the context of empirical analysis of regional firm distribution in general and of specific biotech firm foundations, one can hardly separate the two decisions.

We assume an utility maximizing person and therefore, a firm is usually founded when one's expected utility by entrepreneurial activity exceeds that of alternative occupations. The expected utility depends on distinct variables, such as his or her ambitions regarding personal autonomy and income as well as the respective newly founded firm's survival prospects and expected profitability. Both may be affected by the material and intangible resources available to the potential founder. These resources are then combined in order to realize a competitive advantage; that is, a 
successful implementation of the respective firm's founding concepts (Barney 1991, Peteraf 1993, Prahalad and Hamel 1990).

The resource-based view (RBV) emphasizes material, financial and organisational resources (Penrose 1959, Wernefelt 1984). In correlation with the increased importance of knowledge in certain industries, the knowledge-based view (KBV), an independent theoretical path, was developed. This perspective considers the localization, generation, utilization, transfer and protection of knowledge to comprise the essential foundation of obtaining competitive advantages. With respect to biotechnology, Zucker et al. $(1994,1995,1998)$ and Audretsch and Stephan (1999) go one step further, accentuating the significance of so-called "star scientists". These represent an important stock of knowledge of the modern biotechnology and the possible impact of the development of commercial applications.

Knowledge itself can be categorized as explicit or implicit. In contrast to explicit knowledge, which can be documented and easily communicated (Polanyi 1958)2, implicit knowledge (also called tacit knowledge) constitutes the undocumented knowledge contained within people (Nahapiet and Goshal 1998, Grant 1996, Nonaka and Takeuchi 1995). It is typically the founders themselves who possess the tacit knowledge of particular technologies, products or procedures that served as the foundation of their business ideas. Some of these knowledge resources form an important basis for realizing competitive advantages and thus of income opportunities; these alone, however, are often insufficient. The capacity to share knowledge internally and acquire new knowledge makes a similar contribution. The so called "absorptive capacity", based on a concept developed by Cohen and Levinthal (1990). The acquisition of new knowledge can, for example, occur via the

${ }^{2}$ Polanyi (1958) describes the state of possessing tacit knowledge as ,... knowing more than we can tell. " 
hiring of additional employees, outright appropriation of other firms, joint ventures, or formal/informal cooperations (Kogut and Zander 1992).

Regarding access to external knowledge, a relationship in perceptions concerning firms' choice of location presents itself. According to localization theory, the geographical proximity between players in an innovation system strongly affects implicit knowledge transmission and the generation of spillovers. Since biotechnology is part of a dynamic research field, new scientific insights on technologies and procedures are vital to a biotech firm's survival and success. For this, access to talented and well trained scientists like postgraduate students and laboratory personnel is of particular importance. The significance of geographical proximity was confirmed by a series of studies (Audretsch and Feldman 1996, Anselin et al. 1997). Almeida and Kolgut (1999) determine that the regional agglomeration of knowledge ("knowledge clusters") - access to scientific facilities and a correspondingly trained labor pool - can engender spillovers for firms. A region's endowment of incubation facilities and highly qualified individuals is hence seen as an essential factor of young, innovative firms' choice of location. Marshall's fundamental view emphasizing the advantage of a so called "industrial district" (1890) is expanded by more recent work on the advantage of clusters (Porter 1998). Porter defines these as “...a geographically proximate group of interconnected companies and associate intuitions in a particular field, linked by commonalities and complementarities". According to Porter, positive effects on the productivity of firms and industries, their capacity to innovate and the development of business operations result from the formation of such clusters.

Ultimately, regions equipped with biotechnology-relevant knowledge have two main advantages: First, such areas are more likely to be the site of firm foundations because of the relevant existing resources. Second, a region's available structures can offer advantages to potential founders in the region and elsewhere, provided that said founders put down roots near these facilities. Locally situated potential founders in particular have access to a number of relationships with organizations in a given 
region that could provide them with leverage in implementing their business ideas. The perspective shared by sociological network theory-related discourses (Granovetter 1973, 1985) stresses the importance of social relationships and their influence on economic activity. Stuart and Sorenson (2003: 250) point out that "sociology would appear to have ample opportunity to make a strong contribution to the study of high-technology entrepreneurship". The more strongly positioned a group or individual is within a network (i.e., the more established its social relationships are), the greater its access to required resources will be. From this perspective, it is hardly a surprise that knowledge-intensive firms are often founded in immediate proximity to their founders' work- and living environments. Entrepreneurs of biotechnological ventures who are embedded in these networks do have the chance to take advantage of having access to knowledge, financial institutions etc.

The distinctiveness of regions with biotechnology-relevant knowledge is not limited to potential entrepreneurs who are already "embedded". Embedded means to work in the region of firm location before they became entrepreneurs and having a high affinity to research and science. The attractiveness of available knowledge exerts a pull for "non-embedded founders", meaning entrepreneurs from outside the region as well as entrepreneurs inside the region with low affinity to research and science. Related to theoretical argumentation, non-embedded people are able to increase the access to external knowledge when they start their firms close to research institutes with biotechnology relevant activities. If spillover matters, the number of nonembedded entrepreneurs is positively influenced by the biotechnology relevant knowledge in the target region. From an empirical point of view, the knowledge variables cannot be used to test the role of spillover for "embedded" founders. For this group of founders, the variable measures spillover effects of research institute as well as founder characteristic. We are not able to distinguish both effects if and only if potential founder is considered in the variable. 
Hypothesis 1: Regions with greater endowments of biotechnology-relevant knowledge at public and private research facilities attract more entrepreneurs.

Hypothesis 2: Regions with greater endowments of biotechnology-relevant knowledge generate more spillover and attract more non-embedded entrepreneurs.

\section{Empirical Strategy}

\subsection{Econometric approach}

In analogy to relevant empirical papers (see Bania et al. 1993, Harhoff 1997), we use a count data model to derive the partial effect of knowledge stock on the number of biotechnology founders from 1995 till 2003 on the level of counties. This number can be described with a positive numbered random variable $Y$ following a poison or negative-binomial distribution. A likelihood ratio test can be applied between the two models. The model is parameterised in such a manner that the logarithmic expected value of the number of foundations is a linear function of the explanatory variables: $\ln E(Y)=X \beta$. The matrix $X$ contains $k$ variables by which the relevance of hypotheses is examined (see Table 1). The equation can be estimated via Maximum-Likelihood procedure.

In addition to relevant empirical papers, we take into account the phenomenon of a large share of regions with zero outcomes in the number of biotechnology founders. This observation can be random or persistent over time. Simple count-data models do not differ between the two regimes, and models generate basically biased and inefficient estimates in the case of random observation of zero outcomes. A zeroinflated model offers the opportunity to control for the randomness of zero outcome. In the fist stage, the probability for the observation of zero outcomes (regimeequation) is estimated via Probit- or Logit-model. Subsequently, a simple count data model is estimated. Both stages are estimated simultaneously via Full Information 
Maximum Likelihood estimation (see Mullahey 1986, Greene 1994). The test of Vuong (1989) allows to test between the simple model and the zero-inflated model.

\subsection{Identification of Biotech-Entrepreneurs}

We create an unique dataset to test our hypotheses. The starting point is the ZEWFoundation Panels. This panel dataset has been generated by the ZEW in cooperation with "Creditreform", the largest German credit rating agency (see Almus et al. 2000 for further explanations). The available information includes among other things name and address of the firm, legal form, industry classification, number of employees, sales, foundation date, data regarding insolvency proceedings, date of last enquiry, free flow text with additional information about the firm, i.e. a detailed description of the firm's business activities. Additionally, information regarding owner persons and managers of the firm are recorded in the database. However, the availability of each of the mentioned variables varies considerably.

The identification of biotech-firms in the ZEW-Foundation Panel is based on a computer-assisted search for relevant strings in the description of business activity. The procedure is iteratively. That means, lists of firms are hand-checked and lists of relevant strings are updated. As a result, 874 newly founded firms between 1995 and 2003 with activities in biotechnology-relevant fields have been identified.

In the next step, we prepare data to biotech entrepreneurs. In this paper, an biotech entrepreneur is a person, who is involved with own assets in a newly founded biotech firm and who plays a key role for the firm's business activities. Such a key role will be assumed if the person works in the senior management team of the new firm. In the result, our dataset contains 1,886 entrepreneurs. Data on the home region of entrepreneurs before they engaged in start-up activity is from ZEW-Foundation 
Panel. We checked the plausibility of the data as we start an own inquiry. ${ }^{3}$ The plausibility test show very little differences. ${ }^{4}$ To sum up, Creditrefom data can be used for the approximation of founder's home region.

We are mostly interested in the effect of knowledge spillover generated by public research institutions to push start-ups in their region by "non-embedded" people who worked outside these institutions. Table 2 shows the four groups of entrepreneurs according the local embeddedness and affinity to research of the entrepreneur. All local entrepreneurs with a doctoral degree (= local scientists) form the group of embedded entrepreneurs. Local non-scientists and non-local founders (non-local scientists and non-local non-scientist) count to the group of the nonembedded ones. The differentiation shows that 61 per cent of entrepreneurs are highly embedded. Scientists moving in from other regions are the second important group of biotech entrepreneurs. 5 One fifth of all entrepreneurs are non-local scientists. As expected, non-scientist are less important and provide about one fifth of entrepreneurs.

For the purpose of our empirical analysis, we aggregate individual information to the level of region.

$<$ insert Table 2 around here $>$

\subsection{Exogenous variables}

Table 3 describes our right hand side variables to explain the regional differences in the start-up activity of biotech entrepreneurs. Our knowledge stock variables take into account the heterogeneity of research activity within a region. We differentiate

${ }^{3}$ We collect information on the internet and start an email survey. In the result, biography data are available for 106 scientists which are involved in biotech start-ups.

4 The mean distance between firms' sitting and scientist's home region is 71 kilometres in the ZEW-Foundation Panel, the median is 10 kilometres. The corresponding values in our own inquiry are 85 kilometres (mean) and 12 kilometres (median).

5 The ratio of non-local scientist to all scientist reaches 25 per cent and is lower compared to the 42 per cents of Audretsch and Stephan (1996: 647). 
between research staff at universities and universities of applied science, research staff at other public research institutions and business R\&D personnel.

$<$ insert Table 3 around here $>$

In the context of regional abilities and spillover we consider, whether a region participated at the well-known German BioRegio-Contest (BRC). ${ }^{6}$ Participation in the BRC was attractive for German regions for several reasons: At first, the chance to receive subsidies from federal authorities. Secondly, participation also increases region's prospects of being recognized by investors. Thirdly, the process of concept development facilitate the commercialization of already available biotechnology relevant knowledge in the region and accelerates its transformation into new products. Key players from a region's political, scientific and economic (including financiers) institutions are brought together. According to sociological network research, this interaction is likely to produce spillovers; for example, coordinated measures fostering the establishment of the biotech industry, knowledge sharing and trust, which, among other things, foster the commercialization process. The attendance of the BRC leads to an exclusive possibility of having access to different valuable resources which could arise additional spillovers. Spillovers in BRCparticipating regions may not only result, however, from effects of participation. In addition, it can be assumed that only regions with a critical mass of biotechnology relevant knowledge and actors are able to participate in the contest. The larger the dimension of this ability the greater is the probability to participate at BRC. In the result, BRC participation variables measures effects from unobservable knowledge resources in the region at the time of region's participation decision and spillovers

6 This contest was initiated in 1995 by the Federal ministry of education and research (BMBF) and encouraged regions to apply for subsidies to be used in establishing a biotech industry in the region. The BMBF's main goal was to stimulate the transfer of new knowledge into new products and thereby lessen the distance between Germany and those countries leading in the application of biotechnological knowledge, i.e. the US and Great Britain. Regions were invited to submit a development concept meant to help establish the biotech industry in their region for appraisal (see Dohse 2000 for details). 
from region's participation itself. From an empirical point of view, the variable does not allow a statement about the impact of BRC on start-up activity. ${ }^{7}$

Following the discourse on the establishment of the biotech industry in Germany, more areas began consolidating into smaller and larger BioRegions. Spillovers attributable to this concerted emergence may also arise in these regions. Due to their varying dates of origin, however - some first appeared in 2000 - these are not considered in the following.

Beside the knowledge stock variables we consider the presence of venture capital companies (VCC) in the region. In the line with the argument that proximity between VCC and the capital asking firm may it easier to acquire funding and to support the firm, we expect a positive coefficient estimate. Further we take into account effects based from start-up activity in the neighbourhood and from region's endowment with sufficient and modern industrial real estates.

\section{Estimation results}

Table 4 shows the correlation between explanatory variables. Correlation matrix suggests that multicollinearity problems are of little relevance. Table 5 to Table 7 present the estimation results of the count data model. At first, we give some notes to the model choice. The Likelihood-Ratio test is highly significant and emphasizes to reject the Poisson model. In the next step, we test on the regime of randomness of zero outcomes. The Vuong test statistic is almost significant and suggests the use of zero-inflated models in all cases.

${ }^{7}$ As we applied an instrumental variable (IV), we tried to emphasize the partial effect of BRC. We detect, however, weak instruments and thus, IV-estimates are inconsistent and must not be used (see Bound et al. 1995). In the result, we cannot answer the question about the partial effect of BRC-participation. Details are available upon author's request. 
At first we interpret the results for the determinants of regional differences in the number of all biotech entrepreneurs (Table 5). Knowledge stock at public research institutions contribute significantly to explain the regional differences. As expected, the number of biotech entrepreneurs increases with the knowledge stock. The knowledge stock at private research institutions do not explain the start-up activity. Probably, the high affinity of biotechnology research to science may explain the irrelevance of business $R \& D$ concentration. The result is in accordance with findings of Zucker et al. (1998) for the U.S.. The authors mentioned the insignificance of proximity to pharmaceutical industry. It is worth to note, that startup activity in the neighbourhood correlates positively with start-up activity in the region. In addition, BRC-winners as well as BRC-other participant regions achieve a significant higher number of entrepreneurs of newly founded biotech firms. Most surprisingly, we do not detect any kind of significant differences between the coefficient estimates BRC-winner-regions and BRC-participants ( $\beta_{\mathrm{BRC}-\text {-winners }}=\beta_{\mathrm{BRC}-\text { other }}$ p.). Just like remember, the relevance of spillovers in BRC-participating regions and BRC-winner-regions is not the partial effect of BRC-participation. The positive coefficient only suggests that participants of BRC were more successful to attract biotech-entrepreneurs compared to non-participants. This can be reasoned by unobservable ability of participants and/or effects of participation at BRC. The number of local VCC-offices as well as biotech-start-up activity in previous years do not affect the number of biotech entrepreneurs.

The estimation results are mostly in accordance with our expectations, in particular with our hypothesis 1 . In the following, we focus on results for different groups of entrepreneurs to test our hypothesis 2 which highlights the relevance of knowledge spillover for different groups of entrepreneurs. A significant coefficient for knowledge stock variables can be interpreted as positive spillover effect to attract non-embedded founders. Table 6 presents the results for entrepreneurs with high affinity to research. The results for local scientists are very similar to the findings in Table 5. Again, biotechnology relevant knowledge at public research institutions matter. A few differences are evident for the estimation of non-local scientists. The 
number of non-local scientists establishing a new biotech firm decreases with business R\&D-personnel. In addition, knowledge stock at universities does not affect the moving in from non-local scientists. Only knowledge at non-university public research matter. Most interestingly, BRC-winners attract non-local scientists to higher extent that BRC-other participant regions. The result suggest that additional spillovers based on the exclusive federal support and the label of winner works. Also the presence of VCC matters and contributes to the explanaition of the moving in by non-local scientists. This findings is also supported by econometric analysis of Stuart and Sorenson (2003).

We get totally different results for the start-up activity of non-scientists (Table 7). Neither knowledge variables nor signalling of BRC participation affect the number of entrepreneurs with low affinity to research. In contrast, both estimations is common the positive coefficient estimate for the presence of VCC. The result confirms the attractiveness of regions with high presence of VCC. Making the assumption that the variable only measures advantages of proximity between VCC and firm, outside entrepreneurs moving in the region in order to internalize spillovers from proximity. Only for the sample of non-local entrepreneurs with low affinity to research, we detect that regions with technology and foundation centres are attractive for those. To sum up, other factors may be more important for nonscientists in comparison to scientist to moving in the region.

Our estimation results suggest that research infrastructure attract outside scientists to moving in the region. We interpret the results as evidence for our hypothesis 2 . Knowledge spillover matters and attract mobile founders from research. With respect to differences according the sources for knowledge spillover, universities provide a lower level of knowledge spillovers than other public research institutes. The result may suggest some inefficiencies in the knowledge transfer from universities to entrepreneurs of biotech firms are obvious and potentially hinder the commercialization of knowledge. In alternative manner, someone may argue that the results reflects the institutional differences with respect to the level of teaching and 
research. Universities are more active in teaching and thus, research orientation is per se lower. We believe that only a deeper analysis can answer the question about inefficiencies.

\section{Summary}

Our study aimed at analysing the role of localized knowledge for start-up activity of biotech entrepreneurs. The paper is in line of work presented by Audretsch and Stephan (1996), Zucker et al. (1998) and Stuart and Sorenson (2003). In contrast to theses authors, we suggest an unique approach to test empirically on the role of knowledge spillovers. For these purposes, we classify entrepreneurs according their affinity to research and local embeddedness. The derivation of the hypotheses is based on the concepts of the knowledge based view as well as the economic geography i.e. cluster theory and theory of industrial districts.

The descriptive findings suggest a high importance of local scientist to transfer scientific knowledge to the market. 61 per cent of entrepreneurs of biotech firms founded between 1995 till 2003 become entrepreneurs in their home region. Additionally 20 per cent of biotech entrepreneurs are those with high affinity to research who moved from outside in the region.

As expected, the results of the multivariate analysis indicate a higher start-up activity of biotech entrepreneurs in knowledge intensive regions compared to other regions. Again, the result for all biotech entrepreneurs can be driven by knowledge spillovers and/or entrepreneurs' abilities. A positive impact of knowledge spillover is suggested by our estimation results for different groups of entrepreneurs. We detect a significant positive relationship between knowledge stock at non-university research institutes and the number of entrepreneurs with high affinity to research and moving from outside in the region. We conclude that research infrastructure really attract outside scientists and knowledge spillover matters. In contrast to that, location choice of biotech entrepreneurs with low affinity to science are not affected 
by knowledge stock in the target region. Other factors may be more important for these kind of entrepreneurs to explain the moving in the region.

This conclusion is also supported by findings for efforts of regions to signalize and increase their competencies to establish biotechnology industry successfully. Thus, regions which participated in the BioRegio-contest achieve a significant higher number of biotech entrepreneurs with high affinity to science. Signalling matter to attract outside scientists. In contrast, the number of entrepreneurs with low affinity to science is not determined by participation state.

Region's knowledge stock really attract outside scientists to move in the region. These abilities can be pushed and signalized by the region in different ways. The participation at contests is one prominent example to increase the alertness of outside investors and entrepreneurs successfully.

\section{References}

Agarwal R and Audretsch DB (2001) Does Entry Size Matter? The Impact of the Life Cycle and Technology on Firm Survival. Journal of Industrial Economics 49: 21-43

Almeida P and Kogut B (1999) Localization of Knowledge and the Mobility of Engineers in Regional Networks, Management Science 45(7): 905-917

Almus M, Engel D and Prantl S (2000) The „Mannheim Foundation Panels“ of the Centre for European Economic Research ZEW. German and English Version, ZEW Documentation, No.00-02, Mannheim

Anselin L, Varga A and Acs ZJ (1997) Local Geographic Spillovers Between University Research and High Technology Innovations, Journal of Urban Economics 42: 422-448

Audretsch DB and Feldman MP (1996) R\&D Spillovers and the Geography of Innovation and Production, American Economic Review 86(3): 630-640

Audretsch DB and Stephan PE (1996) Company Scientist Locational Links: The Case of Biotechnology, American Economic Review 86: 641-652

Audretsch DB and Stephan PE (1999) Knowledge Spillovers in Biotechnology: Sources and Incentives, Journal of Evolutionary Economics, 9(1): 97-107

Bania N, Eberts R and Fogarty M (1993) Universities and the Start-Up of New Companies: Can We Generalize from Route 128 and Silicon Valley? Review of Economics and Statistics 75: 761-66

Barney J (1991) Firm resources and sustained competitive advantage. Journal of Management. 17(1): 99-120

Barney J (1991) Firm Resources and Sustained Competitive Advantage. Journal of Management. 17(1): 99-120 
Bound J, Jaeger DA und Baker RM (1995) Problems with Instrumental Variable Estimation when the Correlation between the Instruments and the Endogenous Explanatory Variable Is Weak, Journal of American Statistical Association 90: 443-450

Böventer E v( 1979) Standortentscheidung und Raumstruktur, Hannover

Bruch-Krumbein W and Hochmuth E (2000) Cluster und Clusterpolitik. Begriffliche Grundlagen und empirische Fallbeispiele aus Ostdeutschland, Marburg

Bruederl J, Preisendoerfer P and Ziegler R (1996) Der Erfolg neugegründeter Betriebe: Eine empirische Studie zu den Chancen und Risiken von Unternehmensgründungen, Berlin: Duncker \& Humblot

Cohen WM and Levinthal DA (1990) Absorptive Capacity: A New Perspective on Learning and Innovation, ASQ 35(1): 128-152

Champenois C, Engel D und Heneric O (2003) „Venture Capital bedeutend für die Entstehung der Biotechnologiebranche“, ZEW-GründungsReport 1/2003: 1-2

Dohse D (2000) Technology Policy and the Regions - The Case of the BioRegio Contest, Research Policy 29: 1111-1133

Dolata U (1996) Politische Ökonomie der Gentechnik: Konzernstrategien, Forschungsprogramme, Technologiewettläufe, Berlin

Egeln J, Gottschalk S, Rammer C (2004) Location Decision of Spin-Offs from public Research Institutions

Engel D (2002) Determinanten der regionalen Verteilung Venture Capital-finanzierter Unternehmen, Jahrbuch für Regionalwissenschaft 23: 155-181.

Fier A (2002) Staatliche Förderung industrieller Forschung in Deutschland, ZEW Wirtschaftsanalysen, Bd. 62, Baden-Baden

Frick S, Lageman, von Rosenbladt B, Voelzkow H und Welter F (1998) Möglichkeiten zur Verbesserung des Umfeldes für Existenzgründer und Selbständige - Wege zu einer neuen Kultur der Selbständigkeit, Untersuchungen des RWI, Heft 25, Essen

Gehrung P (1996) Räumliche Ansiedlungsdisparitäten. Empirische Analyse von Bestimmungsfaktoren im Rahmen theoretischer

Granovetter M (1973) The Strength of Weak Ties, American Journal of Sociology 81: 1287-1303

Granovetter M (1985) Economic Action and Social Structure: The Problem of Embeddedness, American Journal of Sociology 91: 481-510

Grant RM (1996) Toward a Knowledge-Based Theory of the Firm, Strategic Management Journal 17: $109-122$

Greene, W. (1994), Accounting for Excess Zeros and Sample Selection in Poisson and Negativ Binomial Regression Models, Working Paper, No. EC-94-10, Department of Economics, Stern School of Business, New York University.

Harding D and Harding R (2001) An International Overview of Public Sector Funding for the Science and Engineering Base, Report to the Office of Science and Technology, Brighton

Harding R (1999) Venture Capital and Regional Development, London

Harding R (2000) Resilience in German Technology Policy: Innovation Through Institutional Symbiotic Tension, Industry and Innovation 7(2): 223-244

Harding R (2001) Competition and Collaboration in German R\&D. Industry and Corporate Change 10(2): 389-417

Harding R (2003) Why Invest in Biotechnology, and How? Britain and Germany Compared, Anglo-German Foundation for the Study of Industrial Society, London

Harhoff D (1997) Innovationsanreize in einem strukturellen Oligopolmodell, Zeitschrift für Wirtschafts- und Sozialwissenschaften 117(3): 323-364

Hoang H und Antoncic B (2003) Network-based research in entrepreneurship: A critical review, Journal of Business Venturing 18: 165-187 
Klepper S (1996), Entry, Exit, Growth, and Innovation over the Product Life Cycle, American Economic Review 80: 562-583

Kogut B and Zander U (1992) Knowledge of the Firm, Combinative Capabilities, and the Replication of Technology. Organization Science. 3: 383-397

Kottmann M (1999) Gentechnik Ja? - Nein? Eine kritische Orientierungshilfe, Stuttgart

Marshall A (1890) Principles of Economics, London

Mullahey, J. (1986), Specification and Testing of Some Modified Count Data Models, Journal of Econometrics 33, 341-365

Nahapiet J and Goshal S (1998) Social Capital, Intellectual Capital, and the Organizational Advantage. Academy of Management Review 22(2): 242-266

Nerlinger E (1998) Standorte und Entwicklung junger innovativer Unternehmen: Empirische Ergebnisse für West-Deutschland, ZEW Wirtschaftsanalysen, 27, Baden-Baden

Nonaka I and Takeuchi H (1995) The Knowledge-Creating Company, New York

Orsenigo L (1989) The Emergence of Biotechnology: Institutions and Markets in Industrial Innovation. London

Penrose E (1959) The Theory of the Growth of the Firm, Oxford (third Edition, 1995)

Peteraf MA (1993) The Cornerstone of Competitive Advantage: A Resourcebased View, in: Journal of Management Studies, 24, 1987, S. 649-670

Pfeiffer F (1994) Selbständige und abhängige Erwerbstätigkeit, Frankfurt a. M.

Polanyi M (1958) Personal Knowledge: Towards a Post- Critical Philosophy, Chicago

Porter M (1998) Clusters and the new Economy of Competition, Harvard Business Review, November: $70-90$

Prahalad, C. K. and G. Hamel (1990). "The Core Competence Of The Corporation." Harvard Business Review 68 (3): 79 - 91.

Sorenson, O. 2003. "Social Networks and Industrial Geography". Journal of

EvolutionaryEconomics 13: 513-527

Storey DJ and Tether B (1996), Review of the Empirical Knowledge and an Assessment of Statistical Data on the Economic Importance of New Technology-Based Firms in Europe, Warwick Research Institute, Coventry.

Stuart T and Sorcnson O (2003) The geography of opportunity: spatial heterogeneity in founding rates and the performance of biotechnology firms, Research Policy 31, 229-253

Swann GMP and Prevezer M (1996) A comparison of the dynamics of industrial clustering in computing and biotechnology, Research Policy 25: 1139-1157

Schlumberger HD and Brauer D (1994) Die Bedeutung rechtlicher Rahmenbedingungen für die Anwendung der Gentechnik in der Bundesrepublik Deutschland in: Schell T von and Mohr H (Eds.), Biotechnologie - Gentechnik. Eine Chance für neue Industrien, Berlin

Schmid RD (2002) Taschenatlas der Biotechnologie und Gentechnik, Weinheim

Vuong Q (1989), Likelihood Ratio Tests for Model Selection and Non-Nested Hypotheses, Econometrica 57, 307-334.

Weber A (1909) Über den Standort der Industrien, Tübingen

Wernefelt B (1984) A Resource-Based View of the Firm, Strategic Management Journal 5: 171180

Winter SG (1984) Schumpeterian Competition in Alternative Technological Regimes, Journal of Economic Behavior and Organization 5: 287-320

Wörner, S, Reiss T, Menrad M and Menrad K (2001) European Biotechnology Innovation Systems - The Case of Germany. Workingpaper 2No.:SOE1-CT98-1117, Karlsruhe 
Zucker L and Darby MR (1995) Virtuous Circles of Productivity : Star Bioscientists and the Institutional Transformation of Industry. NBER Working Paper, No. 5342. NBER, Cambridge, $\mathrm{Ma}$

Zucker L, Darby MR, and Brewer MB (1998) Intellectual Human Capital and the Birth of U. S. Biotechnology Enterprises, The American Economic Review 88: 290-336

Table 1: Description of explanatory variables

\begin{tabular}{|c|c|c|}
\hline Variable & Source & Description \\
\hline $\begin{array}{l}\text { Universities' } \\
\text { staff }\end{array}$ & Statistic of destatis & $\begin{array}{l}\text { Number of scientists in chemistry, biology, } \\
\text { medicine at universities with research } \\
\text { activities in biotechnology according } \\
\text { www.biotech-europe.de in } 1995 \text { (log.) }\end{array}$ \\
\hline $\begin{array}{l}\text { Research. } \\
\text { institutes' staff }\end{array}$ & $\begin{array}{l}\text { Annual reports and own inquiry } \\
\text { of the Max-Planck-, Helmholtz- } \\
\text {, Fraunhofer-, Leibniz-societies. }\end{array}$ & $\begin{array}{l}\text { Number of scientists in technical oriented } \\
\text { public non-university R\&D institutes with } \\
\text { research activities in biotechnology } \\
\text { according www.biotech-europe.de in 1996- } \\
1998 \text { (log.) }\end{array}$ \\
\hline Business & Stifterverband der deutschen & R\&D personnel in business in 1995 (log.) \\
\hline $\begin{array}{l}\text { R\&D- } \\
\text { personnel }\end{array}$ & $\begin{array}{l}\text { Wirtschaft, NIW calculation } \\
\text { and estimation for report } \\
\text { „Technology Competiviness“ }\end{array}$ & \\
\hline High-qualified & $\begin{array}{l}\text { INKAR } 1998 \text { of Federal } \\
\text { Agency for Construction and } \\
\text { Spatial System (BBR) }\end{array}$ & $\begin{array}{l}\text { Employees with degress of } \\
\text { university/university of applied science } \\
\text { related to all employees in } 1996\end{array}$ \\
\hline $\begin{array}{l}\text { Biotech- } \\
\text { startup (t-1) }\end{array}$ & & $\begin{array}{l}\text { Indicator variable with the value one if at } \\
\text { least one biotech-start-ups was founded } \\
\text { between } 1990 \text { and } 1994 \text { and zero otherwise }\end{array}$ \\
\hline BRC-winners & $\begin{array}{l}\text { Dohse }(2000) \text {, own definition at } \\
\text { the level of counties }\end{array}$ & $\begin{array}{l}\text { Indicatorvariable to define winner-regions } \\
\text { of the BioRegio-contest }\end{array}$ \\
\hline $\begin{array}{l}\text { BRC-other } \\
\text { participants }\end{array}$ & $\begin{array}{l}\text { Dohse (2000), own definition at } \\
\text { the level of counties }\end{array}$ & $\begin{array}{l}\text { Indicatorvariable to define other } \\
\text { participants of the BioRegio-contest }\end{array}$ \\
\hline TFC & $\begin{array}{l}\text { Map of German Technology } \\
\text { and Foundation centres } \\
\text { association (ADT) }\end{array}$ & $\begin{array}{l}\text { Indicatorvariable to define counties with } \\
\text { one technology- and foundations centre at } \\
\text { least in } 1999\end{array}$ \\
\hline $\begin{array}{l}\text { Spatial } \\
\text { spillovers }\end{array}$ & & $\begin{array}{l}\text { Sum of biotech-start-ups in counties, } \\
\text { located in radius of } 50 \text { kilometres around } \\
\text { the county under consideration (log.) } \\
\text { (=spatial lag model) }\end{array}$ \\
\hline $\begin{array}{l}\text { Local VCC- } \\
\text { office }\end{array}$ & $\begin{array}{l}\text { Annual yearbook of German } \\
\text { Private Equity association } \\
\text { (BVK) }\end{array}$ & $\begin{array}{l}\text { Number of offices of venture-capital- } \\
\text { companies in the county in } 1999 \text { (log.) }\end{array}$ \\
\hline
\end{tabular}


Table 2: Number of Biotech' entrepreneurs from 1995 till 2003 according the local embeddedness of founders and their affinity to research

\begin{tabular}{|c|c|c|}
\hline \multirow{2}{*}{$\begin{array}{l}\text { Entrepreneur's siting before he } \\
\text { or she becomes an entrepreneur }\end{array}$} & \multicolumn{2}{|c|}{ Entrepreneur's highest educational level } \\
\hline & doctoral degree & $\begin{array}{c}\text { lower than doctoral } \\
\text { degree }\end{array}$ \\
\hline inside the region of firm location & $\begin{array}{l}\text { Local scientist } \\
\qquad(N=1,154)\end{array}$ & $\begin{array}{l}\text { Local non-scientist } \\
\qquad(N=243)\end{array}$ \\
\hline $\begin{array}{l}\text { Outside the region of firm } \\
\text { location }\end{array}$ & $\begin{array}{l}\text { Non-local scientist } \\
\qquad(N=390)\end{array}$ & $\begin{array}{l}\text { Non-local non-scientist } \\
\qquad(N=101)\end{array}$ \\
\hline
\end{tabular}

Bold letters marks the group of embedded-entrepreneurs.

Table 3: Descriptive statistics of explanatory variables

\begin{tabular}{lrrrr}
\hline & Mean & St.Deviation & Minimum & Maximum \\
\hline Universities' staff & 0.927 & 2.288 & 0.000 & 8.620 \\
Res. institutes'staff & 0.416 & 1.363 & 0.000 & 7.054 \\
Busin. R\&D personnel & 5.123 & 1.606 & 0.000 & 10.280 \\
High-qualified & 0.063 & 0.033 & 0.019 & 0.222 \\
Biotech-startup (t-1) & 0.458 & 0.498 & 0 & 1 \\
BRC-winners & 0.046 & 0.209 & 0 & 1 \\
BRC-other participants & 0.080 & 0.271 & 0 & 1 \\
TFC & 0.296 & 0.457 & 0 & 1 \\
Spatial spillover & 2.352 & 1.243 & 0.000 & 4.673 \\
Local VCC-office & 0.097 & 0.437 & 0.000 & 3.761 \\
\hline
\end{tabular}

Table 4: Correlations between explanatory variables

\begin{tabular}{llccccccccc}
\hline & 1 & 2 & 3 & 4 & 5 & 6 & 7 & 8 & 9 \\
\hline 1 & Universities' staff & 1.00 & & & & & & & & \\
2 & Res. institutes'staff & 0.39 & 1.00 & & & & & & & \\
3 & Busin. R\&D personnel & 0.36 & 0.25 & 1.00 & & & & & & \\
4 & High-qualified & 0.48 & 0.35 & 0.45 & 1.00 & & & & & \\
5 & Biotech-startup (t-1) & 0.24 & 0.23 & 0.34 & 0.23 & 1.00 & & & & \\
6 & BRC-winners & 0.16 & 0.28 & 0.27 & 0.23 & 0.17 & 1.00 & & & \\
7 & BRC-other participants & 0.47 & 0.38 & 0.28 & 0.36 & 0.24 & -0.06 & 1.00 & & \\
8 & TFC & 0.27 & 0.14 & 0.15 & 0.25 & 0.09 & 0.07 & 0.09 & 1.00 & \\
9 & Spatial spillover & 0.06 & 0.11 & 0.35 & 0.12 & 0.25 & 0.24 & 0.13 & -0.03 & 1.00 \\
10 & Local VCC-office & 0.47 & 0.33 & 0.36 & 0.39 & 0.21 & 0.22 & 0.34 & 0.07 & 0.15 \\
\hline
\end{tabular}


Table 5: Determinants of the number of entrepreneurs of biotech firms founded between 1995 and 2003

\begin{tabular}{lrc}
\hline & \multicolumn{2}{c}{ All founders } \\
Explanatory variables & coeff. & st-error \\
\hline Universities' staff & $0.148 * * *$ & 0.029 \\
Res. institutes'staff & $0.159 * * *$ & 0.037 \\
Busin. R\&D personnel & -0.003 & 0.064 \\
High-qualified & 0.591 & 2.453 \\
Biotech-startup (t-1) & 0.064 & 0.180 \\
BRC-winners & $1.132 * * *$ & 0.222 \\
BRC-others & $0.779 * * *$ & 0.175 \\
TFC & 0.054 & 0.135 \\
Spatial spillover & $0.139 * *$ & 0.057 \\
Local VCC-office & 0.112 & 0.093 \\
Intercept & 0.343 & 0.338 \\
alpha(ln) & -0.419 & \\
\hline \# of observations & 439 & \\
- zero outcomes & 226 & \\
$\beta_{\text {BRC-winners }} \beta_{\text {BRC-others }}$ & 2.48 & \\
Likelihood Ratio Test & & \\
Poisson vs. NegBin & $856.81 * * *$ & \\
Vuong-Statistik & & \\
zero-inflated vs. & $3.30 * * *$ & \\
simple model & & \\
\hline
\end{tabular}

*** $(* *)\{*\}$ significant at $1(5)\{10\}$ percent-level of significance. Result of zero-inflated negativ-binomial-model with heteroscedastic robust standard errors. 
Table 6: Determinants of the number of scientific entrepeneurs of biotech start-ups founded between 1995 and 2003

\begin{tabular}{lrrrrr}
\hline & \multicolumn{2}{c}{ Local } & \multicolumn{3}{c}{ non-local } \\
Explanatory variables & coeff. & st-error & coeff. & st-error \\
\hline Universities' staff & $0.204 * * *$ & 0.044 & 0.062 & 0.044 \\
Res. institutes'staff & $0.184 * * *$ & 0.057 & $0.144 * *$ & 0.058 \\
Busin. R\&D personnel & 0.046 & 0.102 & -0.331 & $* * *$ & 0.100 \\
High-qualified & 1.357 & 3.943 & 1.256 & 3.968 \\
Biotech-startup (t-1) & 0.212 & 0.397 & $-0.751 *$ & 0.402 \\
BRC-winners & $1.037 * * *$ & 0.432 & $2.368 * * *$ & 0.420 \\
BRC-others & $0.654 * * *$ & 0.296 & $1.479 * * *$ & 0.297 \\
TFC & $-0.33 *$ & 0.268 & -0.146 & 0.265 \\
Spatial spillover & 0.084 & 0.100 & -0.011 & 0.092 \\
Local VCC-office & -0.068 & 0.119 & $1.479 * * *$ & 0.297 \\
Intercept & -0.28 & 0.546 & -0.146 & 0.265 \\
alpha(ln) & -0.275 & & 0.114 & \\
\hline \# of observations & 439 & & 439 & \\
- zero outcomes & 298 & & 337 & \\
$\beta_{\text {BRC-winners }} \beta_{\text {BRC-other p. }}$ & 2.09 & & $5.21 * *$ & \\
Likelihood Ratio Test & & & & \\
Poisson vs. NegBin & $573.78 * * *$ & & $275.40 * * *$ & \\
Vuong-Statistik & & & & & \\
zero-inflated vs. & $3.02 * * *$ & & & \\
simple model & & & & & \\
\hline
\end{tabular}

*** $(* *)\{*\}$ significant at $1(5)\{10\}$ percent-level of significance. Result of zero-inflated negativ-binomial-model with heteroscedastic robust standard errors. 
Table 7: Determinants of the the number of non-scientific entrepeneurs of biotech startups founded between 1995 and 2003

\begin{tabular}{lrrrr}
\hline & \multicolumn{2}{c}{ Local } & \multicolumn{2}{c}{ non-local } \\
Explanatory variables & coeff. & st-error & coeff. & st-error \\
\hline Universities' staff & 0.006 & 0.038 & 0.023 & 0.035 \\
Res. institutes'staff & 0.026 & 0.056 & 0.050 & 0.046 \\
Busin. R\&D personnel & -0.075 & 0.082 & 0.009 & 0.069 \\
High-qualified & 3.727 & 3.494 & 3.247 & 3.071 \\
Biotech-startup (t-1) & 0.154 & 0.291 & -0.057 & 0.207 \\
BRC-winners & 0.016 & 0.510 & -0.003 & 0.444 \\
BRC-others & 0.242 & 0.395 & 0.371 & 0.280 \\
TFC & 0.506 & 0.312 & $0.380 * *$ & 0.167 \\
Spatial spillover & 0.104 & 0.084 & $0.137 *$ & 0.074 \\
Local VCC-office & $0.480 * * *$ & 0.119 & $0.330 * * *$ & 0.102 \\
Intercept & -0.504 & 0.628 & -0.608 & 0.491 \\
alpha(ln) & -1.529 & & 0.151 & \\
\hline \# of observations & 439 & & 439 & \\
- zero outcomes & 324 & & 304 & \\
$\beta_{\text {BRC-winners }} \beta_{\text {BRC-other p. }}$ & 0.55 & & $2.89 *$ & \\
Likelihood Ratio Test & & & & \\
Poisson vs. NegBin & $53.09 * * *$ & & $3.30 * *$ & \\
Vuong-Statistik & & & & \\
zero-inflated vs. & $2.47 * * *$ & & & \\
simple model & & & & \\
\hline
\end{tabular}

*** $(* *)\{*\}$ significant at $1(5)\{10\}$ percent-level of significance. Result of zero-inflated negativ-binomial-model with heteroscedastic robust standard errors. 